http://dx.doi.org/10.11646/phytotaxa.161.1.1

\title{
Do you know Cyathea divergens (Cyatheaceae-Polypodiopsida)?
}

\author{
MARCUS LEHNERT ${ }^{1,2}$ \\ ${ }^{1}$ Nees Institut für Biodiversität der Pflanzen, Rheinische-Friedrich-Wilhelms Universität Bonn, Meckenheimer Allee 170, 53115 \\ Bonn, Germany \\ ${ }^{2}$ Staatliches Museum für Naturkunde Stuttgart, Abt. Botanik, Am Löwentor, Rosenstein 1, 70191 Stuttgart, Germany \\ Email:mlehnert@uni-bonn.de
}

\begin{abstract}
The Neotropical scaly tree fern Cyathea divergens is a paradigm of a variable species with a wide geographical range. Studies in herbaria and in the field reveal that $C$. divergens is less frequently collected and less variable than previously thought. A lot of records are based on fragmentary collections of similar species that have the characteristically longstalked, triangular, pinnatisect pinnules and sparse to absent laminar indument in common, but differ in other characters. Their separation from $C$. divergens is easy if petiolar characters are considered and even possible if microscopic remnants of the fine scurf on the pinnules are studied. Cyathea tuerckheimii is given here species status, eliminating one variety of $C$. divergens, whereas $C$. divergens var. sipaliwiniana is newly described. Cyathea convergens, here newly described, also belongs to this group. The identification of Cyathea $\times$ jurgensenii as a sterile hybrid between $C$. tuerckheimii and $C$. fulva reduces the confusion that exists in the separation of $C$. tuerckheimii from $C$. divergens and $C$. fulva. The typification of Cyathea kalbreyeri is corrected here. The type specimen of that species represents a previously unrecognized species, while the specimens known under that name are similar to the type of Cyathea gibbosa, which in turn currently denominates a species that has to be referred to as Cyathea farinosa. One synonym of C. gibbosa, C. surukunensis, may represent a hybrid.
\end{abstract}

\section{Introduction}

Tree ferns are easily spotted in the field, but difficult to collect properly. The huge size of the leaves and stems that most species reach at maturity put certain limitations to the completeness of collections. Fragmentary collections are inevitable, but there is a minimum amount of the leaf (petiole, basal pinna, medial pinna and apex) that has proven to be sufficient for comparative morphological studies and for delimiting and characterizing species confidently (see also collection methods of Dransfield 1986, Christenhusz \& Tuomisto 2005 and Janssen 2006). Nowadays collections are easily upgraded by digital images, which give a better general impression of the whole plant. However, it is often the type material that does not meet these minimum requirements and thus many names are often difficult to apply correctly, especially without studying sufficient material from type localities.

A paradigm of incomplete specimens and consequent morphological misconception is Cyathea divergens Kunze (1834: 100). The type at Leipzig was destroyed during WWII and the remaining authentic material lacks petioles, which bears crucial morphological features in this group. The petiole characters are not mentioned in the diagnosis and the trunk is only described superficially, not being helpful in assigning this name to modern collections. A surprisingly large amount of collections of this species lacks a petiole, more than in any other large tree fern species with similar distribution and frequency. With few petioles available to compare and no type petiole to compare them with, the determination of $C$. divergens was based on its characteristic fronds. They are notable for their long-stalked, clearly triangular pinnules with truncate to cordate bases, among which the largest are usually more than $2 \mathrm{~cm}$ wide, the firm-chartaceous to subcoriaceous texture and almost completely glabrous laminae.

In the revision of the genus Cyathea, Tryon (1976) defined $C$. divergens as a widespread and variable species with pale, whitish petiole scurf and brown petiole scales with white margins. He did not detect strong patterns in 
received support from the SYNTHESYS Project (http_//www.synthesys.info/), which is financed by European Community Research Infrastructure Action under the FP6 "Structuring the European Research Area" Programme.

\section{References}

Antunes Carvalho, F., Salino, A. \& Zartman, C.E. (2013) New country and regional records from the Brazilian side of Neblina Massif. American Fern Journal 102: 228-232.

http://dx.doi.org/10.1640/0002-8444-102.3.228

Baker, J.G. (1877) New ferns from the Andes of Quito. Journal of Botany, British and Foreign 15: 161-168.

Baker, J.G. (1881) On a collection of ferns made by Mr. W. Kalbreyer in New Grenada. Journal of Botany, British and Foreign 19: 202-208.

Baker, J.G. (1891) A summary of the new ferns which have been discovered or described since 1874. Annals of Botany (Oxford) 5: 118-222, 301-332. http://dx.doi.org/10.5962/bhl.title. 19884

Baker, J.G. (1894) New Ferns of 1892/93. Annals of Botany (Oxford) 8: 12-132.

Barrington, D.S. (1976) New taxa and nomenclatural changes in the genus Trichipteris. Rhodora 78: 1-5. http://www.jstor.org/stable/23311305

Barrington, D.S., Paris, C.A. \& Ranker T.A. (1986) Systematic inferences from spore and stomate size in the ferns. American Fern Journal 76: 149-159. http://dx.doi.org/10.2307/1547723

Brown. R. (1810) Prodromus Florae Novae Hollandiae et Insulae van-Diemen. Vol. I. R. Taylor, London, 590 pp.

Christ, H. (1904) Primitiae Florae Costaricensis: Filices et Lycopodiaceae. Bulletin de l'Herbier Boissier II, 4: $936-951$.

Christ, H. (1905) Filices Uleanae Amazonicae. Hedwigia 44: 368-370.

Christenhusz, M.J.M. \& Tuomisto, H. (2005) Some notes on the taxonomy, biogeography and ecology of Danaea (Marattiaceae). Fern Gazette 17: 217-222.

Christensen, C.F.A. (1905) Index Filicum. Hagerup, Copenhagen, 744 pp.

Domin, C. (1929) Pteridophyta. Ceske Akademie, Prague, 276 pp.

Domin, C. (1930) The species of the genus Cyathea J.Sm. Acta Botanica Bohemica 9: 85-174.

Dransfield, J. (1986) A guide to collecting palms. Annals of the Missouri Botanical Garden 73: 166-176. http://dx.doi.org/10.2307/2399148

Fée, A.L.A. (1857) Catalogue methodique des fougerès et des Lycopodiacees du Mexique. Mémoires sur la famille des fougères 9. Berger-Levrault, Strassbourg, 48 pp.

Fournier, E.P.N. (1872) Mexicanas plantas nuper a collectoribus expeditionis scientificae allatas aut longis ab annis in herbario musei parisiensis depositas. Typographeus Reipublicae, Paris, $166 \mathrm{pp}$.

Gastony G.J. (1979) Spore morphology in the Cyatheaceae. III. The Genus Trichipteris. American Journal of Botany 66: 12381260. http://dx.doi.org/10.2307/2442221

Givnish, T.J., Millam, K.C., Evans, T.M., Hall, J.C., Pires, J.C., Berry, P.E. \& Sytsma, K.J. (2004) Ancient vicariance or recent long-distance dispersal? Inferences about phylogeny and South American-African disjunctions in Rapateaceae and Bromeliaceae based on $n d h f$ sequence data. International Journal of Plant Sciences 165 (4 Suppl.): S35-S54. http://dx.doi.org/10.1086/421067

Grisebach, A.H.R. (1864) Flora of the British West Indian Islands. Lovell Reeve, London, 789 pp.

Hieronymus, G. (1904) Plantae Lehmanniae in Guatemala, Columbia et Ecuador regionibusque finitimis collectae, additis quibusdam ab aliis collectoribus ex iisdem regionibus allatis determinatae et descriptae. Pteridophyta. Botanische Jahrbücher 34: 417-582.

Holdridge, L. (1947) Determination of world plant formations from simple climatic data. Science 105: 367-368. http://dx.doi.org/10.1126/science.105.2727.367

Holttum, R.E. \& Edwards, P.J. (1983) The tree ferns of Mount Roraima and neighbouring areas of the Guyana Highlands with comments on the family Cyatheaceae. Kew Bulletin 38: 155-188.

http://dx.doi.org/10.2307/4108100

Hooker, W.J. (1857) Florula Honkongensis: The Filices. Hooker's Journal of Botany and Kew Garden Miscellany 9: 333-344.

Hooker, W.J. (1865) Synopsis filicum, part 1. Pamplin, London, pp. 1-32.

Im Thurn, E.F. (1886) Notes on the plants observed during the Roraima expedition of 1884. Timehri 5: 147-223.

Janssen, T. (2006) A moulding method to preserve tree fern trunk surfaces including remarks on the composition of tree fern herbarium specimens. Fern Gazette 17: 283-295.

Jenman, G.S. (1898) The Ferns and Fern allies of the British West Indies and Guiana. Hart, Port of Spain, 407 pp. 
Karsten, H. (1856) Plantae Columbianae. Linnaea 28: 341-352, 387-462.

Karsten, H. (1869) Flora Columbiae terrarumque adjacentium specimina selecta in peregrinatione duodecim annorum observata 2, fasc. 2-3: 41-114.

http://dx.doi.org/10.5962/bhl.title.400

Klotzsch, J.F. (1844) Beiträge zu einer Flora der Aequinoctial-Gegenden der neuen Welt. Linnaea 18: 515-556. http://dx.doi.org/10.5962/bhl.title.6148

Kuhn, F.A. (1869) Reliquiae Mettenianae. Linnaea 36: 41-169.

Kunze, G. (1834) Synopsis plantarum cryptogamicarum ab Eduardo Poeppig in Cuba Insula et America Meridionali collectarum. Linnaea 9: 1-111. http://dx.doi.org/10.5962/bhl.title.51054

Lehnert, M. (2003) Six new tree ferns from the Andes. American Fern Journal 93: 169-183. http://dx.doi.org/10.1640/0002-8444(2003)093[0169:snsotf]2.0.co;2

Lehnert, M. (2009a) Three new species of scaly tree ferns (Cyathea-Cyatheaceae) from the northern Andes. Phytotaxa 1: 4356. http://dx.doi.org/10.11646/phytotaxa.1.1.5

Lehnert, M. (2009b) Resolving the Cyathea caracasana-complex (Cyatheaceae). Stuttgarter Beiträge für Naturkunde A, Neue Serie 2: 409-445. http://www-alt.naturkundemuseum-bw.de/stuttgart/pdf/a_pdf/NS02-12.pdf

Lehnert, M. (2011) Species of Cyathea in America related to the western Pacific species C. decurrens. Phytotaxa 26: 39-59. http://www.mapress.com/phytotaxa/content/2011/f/pt00026p059.pdf

Losch, I. (1951) Neue Farne aus Costa Rica. Mitteilungen der Botanischen Staatssammlung München 67: $20-24$.

Martens, M. \& Galeotti, H.G. (1842) Mémoire sur les Fougères du Mexique, et considérations sur la géographie botanique de cette contrée. Nouveaux mémoires de l'Académie Royale des Sciences et Belles-Lettres de Bruxelles 15: 1-100. http://dx.doi.org/10.5962/bhl.title.51544

Maxon, W.R. (1909a) Studies of Tropical American ferns, No. 2. Contributions from the United States National Herbarium 13: $1-43$.

Maxon, W.R. (1909b) Cyatheaceae. North American Flora 16: 65-89.

Maxon, W.R. (1946) New Cyatheaceae from Colombia. Journal of the Arnold Arboretum 27: 438-441.

Mickel, J.T. \& Smith, A.R. (2004) The Pteridophytes of Mexico. Memoirs of the New York Botanical Garden 88: 1-1055.

Mettenius, G.H. (1859) Filices Lechlerianae, chilenses ac peruanae 2. Hohenacker, Leipzig, 38 pp.

Mettenius, G.H. (1864) Prodromus Florae Novo-Granatensis. Filices. Annales des Sciences Naturelles, Botanique V, 2: 193271.

Monterrosa, J. \& Monro, A.K. (2008) An annotated checklist of the Monilophytes (ferns) and Lycophytes of El Salvador. The Fern Gazette 18: 120-215.

Moore, T. (1857) Index filicum, a synopsis with characters of the genera and an enumeration of the species of ferns, with synonyms, references, etc. Pamplin, London, $396 \mathrm{pp}$.

Moore, T. (1861) Index filicum, a synopsis with characters of the genera and an enumeration of the species of ferns, with synonyms, references, etc. Pamplin, London, $396 \mathrm{pp}$.

Moran, R. C. (1991) Eight new species of tree ferns (Cyathea, Cyatheaceae) from the American tropics and three new combinations. Novon 1: 88-104.

Moran, R. C. (1995) Five new species and two new combinations of ferns (Polypodiopsida) from Ecuador. Nordic Journal of Botany 15: 49-58.

Morton, C.V. (1951) Botanical Exploration in Venezuela I. Cyatheaceae. Fieldiana, Botany 28: 7-16.

Pittier, H. (1901). Primitiae Florae Costaricensis. Filices III. Jardin botanique de l'état, Brusells, 69 pp.

Poeppig, E.F. (1856) Reise in Chile, Peru. 2. Fleischer, Leipzig, 464 pp.

Presl, C. (1847) Die Gefässbündel im Stipes der Farrn. Haase, Prague, 48 pp., 7 pl.

Presl, C. (1849 [1851]) Epimeliae Botanicae. Haase, Prague, 264 pp. http://dx.doi.org/10.5962/bhl.title.61845

Rosenstock, E. (1925) Filices novae a cll. Alfred et Curt Brade in Costarica collectae. Repertorium novarum specierum regni vegetabilis 22: 2-23.

http://dx.doi.org/10.1002/fedr.4870220103

Smith, A.R. (1990) Pteridophytes of the Venezuelan Guayana: New Species. Annals of the Missouri Botanical Garden 77: 249 273. http://dx.doi.org/10.2307/2399539

Smith, A.R. (2006) New species of ferns from the Río Cenepa area, Amazonas, Peru. Novon 16: 424-432. http://dx.doi.org/10.3417/1055-3177(2006)16[424:nsofft]2.0.co;2

Trevisan, V.B.A. (1851) Sopra alcuni nuovi generi, e trentadue nuove specie di Felci. Atti del reale Istituto Veneto di Scienze, Lettere ed Arti 2: 161-168. 
Tryon, R.M. (1970) The classification of the Cyatheaceae. Contributions from the Gray Herbarium 200: 3-50.

Tryon, R.M. (1976) A revision of the genus Cyathea. Contributions from the Gray Herbarium 206: 19-98.

Véliz, M. \& Vargas, J. (2006) Helechos arborescentes de Guatemala-Distribución, diversidad, usos y manejo. Herbario BIGU, Universidad de San Carlos de Guatemala, 94 pp.

Windisch, P.G. (1973) Filices novae Austroamericanae I. Bradea 1: 371-378.

Windisch, P.G. (1978) The systematics of the group of Sphaeropteris hirsuta (Cyatheaceae). Memoirs of the New York Botanic Garden 29: 2-22. 